J. L. Cope in 1921 along with T. W. Bagshaw and M. C. Laster.

One of his most spectacular proposais, however, was his putting forward the idea of taking a submarine under the arctic pack-ice, and by the effort which he made with Lincoln Ellsworth in 1931 he was thus anticipating the successful voyages made by a later Nautilus in 1958.

One of Wilkins's earlior associations with Lincoln Ellsworth had led to an important flight across a sector of Antarctica in December 1928. On this occasion a message reached Britain from Wilkins, who was on board ship, that Ellsworth had got into difficulties after reaching the edge of the Ross Barrier together with his pilot, Ben Eielson. This led the British Colonial Office to arrange that the William Scoresby should be diverted at short notice to the Antarctic, and Ellsworth and Eielson were picked up without difficulty.

Wilkins, on these flights in December 1928, had stated that Graham Land was insular. This led to much confusion at the time and attempts to identify places in Graham Land such as Stefansson Strait and Crane Channel. The matter was not cleared up until the Rymill Expedition began surveys in 1934 . Wilkins had, in fact, regarded as straits what in reality were glaciers. At the time, however, Wilkins's claims to have discovered 'Hearst Land' and 'Stefansson Strait' were a source of controversy.

Hubert Wilkins was one of the earliest explorers of the air age, and his picturesque figure with his short, trim beard made him well known and popular in the United States, where he had made his home. J. M. WORDIE

\section{Prof. Florence A. Mockeridge}

Florence Annte Mockeridge, emeritus professor of botany in the University College of Swansea, died on December 18 at the age of sixty-nine.

Florence Mockeridge studied first at Woolwich Polytechnic (Penfold gold medallist) and then at King's College, London, as a Merchant Taylor's Company Scholar. She graduated with first-class honours in the Pass B.Sc. in 1909 and again in the Honours B.Sc. in 1910 and was awarded the Carter Gold Medal of King's College. During 1911-17 she undertook research with Prof. W. B. Bottomley, first as a Layton Research Student and later with grants from the Board of Agriculture and Fisheries. During this period she was engaged upon pioneer studies on nitrogen fixation by Azotobacter and on the growth-promoting substances ('auximones') of natural manures. Her published researches in this field led, in 1917, to the award of the D.Sc. (London). During 1917-22 she was successively demonstrator and University lecturer in botany at King's College and, continuing her researches, demonstrated the presence in natural manures of nucleic acid degradation products, including the purine bases, and examined their growth-promoting activities.

In 1922, Dr. Mockeridge was appointed independent lecturer in botany in charge of the Department of Biology of the newly established University College of Swansea. Here, in improvized accommodation and with a very small staff, she built up, over a period of thirty-two years, the reputation of the honours degree in botany and directed the work of a succession of research students. Her outstanding ability as a teacher and her scientific achievements in the face of inadequate facilities and often indif- ferent health were recognized by her election in 1936 as the first professor of botany in the College. She long pressed for the establishment of separate Departments of Botany and Zoology, and when, shortly before her retirement in 1954, this was to become possible by the decision to erect a new Natural Sciences Building (Nature, 179, 124; 1957) she planned the new facilities with great eare and wisdom in full knowledge that their use would be for her successors.

Prof. Mockeridge also played a big part in the development of the University College, being dean of the faculty of science during 1933-35 and again during 1941-43, vice-principal during 1949-51 and, for many years, treasurer of the Student's Representative Council. She took a deep personal interest in the welfare and continuing progress of her students, whose affection and respect for her were recently expressed by their presentation to the Department of Botany of her portrait in oils.

She was always much sought after as a lecturer all over South Wales. For many years she was editor of the Proceedings of the Swansea Field Naturalists' Society. On her retirement she became chairman of the Science Committee of the National Museum of Wales and a member of the Glantawe Hospitals Management Committeo. H. E. STREeT

\section{Sir Ralph Pearson, C.I.E.}

Raxph Sneyd Pearson, who died on December 8, aged eighty-four, was educated at the Royal Indian Engineering College, Coopers Hill, and joined the Indian Forest Service in 1898.

After service as a territorial forest officer in the Bombay province, he was posted to the Forest Research Institute, Dehra Dun, to take charge of the recently formed Economic Branch in 1909. Until 1920 he had to work largely single-handed, devoting special attention to the adoption by the railways of antiseptically treated sleepers to relieve the heavy demands on the supply of naturally durable timbers. $\mathrm{He}$ also surveyed the possibility of using bamboo for paper-making on a commercial scale.

In 1920 the Economic Branch was much enlarged by the formation of several sections dealing with special aspects of the utilization of forest products, and Pearson was sent to Canada and the United States to recruit specialists to take charge of some of them. It was then that the results of the work he had done before and during the First World War began to gain the general acceptance they have since received with great benefit to Indian industry.

In 1925 he retired from the Indian Forest Service and returned to Britain, where he was appointed director of the new Forest Products Research Laboratory (Department of Scientific and Industrial Research), which he built up very much on the lines of his branch at Dehra Dun. There he remained until 1933, when he had to retire for reasons of health.

He was made C.I.E. in 1920 and was knighted in 1933; he received the honorary degree of LL.D. of the University of St. Andrews.

The author of several monographs on various forest products, his chief work was "The Commercial Timbers of India", written in collaboration with the late H. R. Brown, of the New York State College of Forestry. $\mathrm{He}$ was a good shot and a very keen cricketer who was always very popular with his staff.

He married Constance Ommaney, who died in 1938 , and he is survived by two sons and a daughter. W. A. Robertson 